DE DE GRUYTER OPEN

\title{
The relationship between receptive and productive vocabulary of Slavic EFL learners
}

\author{
Zdislava Šišková \\ University of Economics, Czech Republic
}

\begin{abstract}
This study investigates the relationship between learners' receptive vocabulary knowledge as measured by the Vocabulary Size Test (Nation and Beglar, 2007) and free productive vocabulary knowledge as demonstrated by the learners when writing a short story based on pictures. The focus is on three different areas of productive vocabulary use: lexical diversity (i.e. the proportion of different words in a text), lexical sophistication (i.e. the proportion of advanced words in a text) and lexical density (i.e. the proportion of content words in a text). The results of a bivariate correlation analysis indicate that there is a moderate relationship between learners' receptive vocabulary knowledge and lexical diversity of the texts they produce; there is a weak relationship between their receptive vocabulary knowledge and lexical sophistication in the texts; and there is no relationship between their receptive vocabulary knowledge and lexical density.
\end{abstract}

\section{Keywords}

receptive vocabulary knowledge, productive vocabulary knowledge, controlled productive vocabulary knowledge, free productive vocabulary knowledge, lexical richness; lexical diversity, lexical sophistication, lexical density

\section{Introduction}

Vocabulary is a key component of language and even though this area of language proficiency had been largely neglected in favour of grammar until the 1980s (Meara, 1980), research focusing on vocabulary acquisition has been developing rapidly and dynamically since then (Daller, Milton and Treffers-Daller, 2007). In the 1990s, Lewis (1993) argued that "language consists of grammaticalized lexis, not lexicalized grammar" (p. 89) since he was convinced of the central role of lexis in language. In the 2000s, Vermeer (2001) claimed that "knowledge of words is now considered the most important factor in language proficiency and school success" (p. 217). In the 2010s, Schmitt (2010) published his vocabulary research manual where he provides evidence, based on previous empirical studies, that knowledge of vocabulary is essential in L2 learning since measures of vocabulary size correlate highly with language proficiency and language skills. Knowledge of words is important when learning and using both the native language and foreign languages since words carry the semantic meaning, and it is virtually impossible to comprehend or produce messages (beyond communicating just very basic meaning) without their knowledge (Vermeer, 2001).

\subsection{Vocabulary knowledge}

Vocabulary knowledge is a complex construct and as Schmitt (2014, p.913) 
suggests "the exact nature of lexical knowledge has always perplexed researchers and teachers". There is no universal definition of what it means to "know a word" but researchers generally agree that it is not possible to simply say that a learner either knows or does not know a certain word (e.g. Laufer and Paribakht, 1998; Nation, 2001; Schmitt, 2000; 2010; 2014). Rather than that, vocabulary knowledge is generally seen as consisting of several (related) components (Nation, 2001) or as a continuum which includes several progressive levels of knowledge, from a very superficial knowledge when a person recognizes a group of letters or sounds as a word existing in a certain language through the connection between the form and one or more of its meanings to complex understanding of what the word can mean in various contexts and the ability to use it appropriately (Schmitt, 2010). Henriksen (1999), for example, proposes three "separate but related" (p. 304) dimensions of lexical competence, which may reflect three continua along which it is possible to describe lexical development: a partial precise knowledge dimension, a depth of knowledge dimension and a receptive productive dimension.

The distinction between receptive (also sometimes called passive) and productive (also sometimes called active) knowledge of a word is very common, even though the two terms are not always understood in the same way (Laufer, Elder, Hill, and Congdon, 2004; Laufer and Goldstein, 2004). In most cases and in this study, receptive knowledge is interpreted as being able to recall the meaning of a word when one is presented with its form and productive knowledge is seen as an ability to produce the right form to express the required meaning (Laufer et al., 2004; Laufer and Goldstein, 2004; Nation, 2001; Schmitt, 2010). Receptive knowledge is therefore often measured by translating from L2 into L1 or by other tests in which test-takers are presented with a word in $\mathrm{L} 2$ and have to indicate whether they know the meaning (e.g. by choosing a picture corresponding with the meaning, which is the basis of the Peabody Picture Vocabulary Test created by Dunn and
Dunn, 2007, or by choosing the right definition or a synonym). Productive knowledge is often measured by translating from L1 into L2, by cloze tests or by analysing vocabulary in learner speech or writing. As Laufer (1998) and Laufer and Paribakht, (1998) suggest, it is often useful to distinguish between two kinds of productive knowledge: "controlled" productive and "free" productive. Controlled productive knowledge is usually tested in cloze or translation tests which are generally designed to test whether L2 learners can produce specific vocabulary items selected by the test designers based on certain criteria (e.g. curriculum requirements or frequency). Learners are thus "forced" to use a certain word that fits the required meaning and context without much freedom of choice. When testing free productive vocabulary knowledge learners are usually asked to produce a sample of written or spoken discourse and it is up to them which words they will choose to use to express themselves. Although restrictions, given for example by the topic and register, are also present to a certain extent, this kind of task allows much more freedom.

\subsection{Measuring vocabulary knowledge}

When measuring vocabulary knowledge (both receptive and productive), it is essential to specify what is meant by a "word" (Read, 2007) since different definitions of what a "word" is lead to considerable differences in research results (Treffers-Daller, 2011). In order to express how long a text or a sentence is, words are usually counted as "tokens". This means that every word is counted each time it occurs. If we are, however, interested in how many different words there are in a text or a sentence, then we define words as "types". In this case, every word is counted only the first time it appears. The type-token ratio is one of the basic measures of lexical diversity (also used in this study). Since evidence suggests that learners see words that are closely related as belonging together, words are sometimes defined as "word families" for the purposes of vocabulary learning. For instance, if an L2 student is 
able to recognize or produce the word $d o g$, it is reasonable to assume that he or she will also be able to recognize or produce the regular plural dogs. These two word forms belong to the same word family. The size of the family can differ depending on how narrowly or widely it is defined (Nation and Meara, 2010).

Word families are usually the basis of creating word frequency lists (Read, 2007). When selecting words for theory-based tests of vocabulary size (Bachman and Palmer, 1996), researchers often build on the assumption that learners are likely to acquire the vocabulary used most frequently in English first and the vocabulary used less frequently later. Even though this might not necessarily be the case in contexts where students learn English as a foreign language with limited access to naturally used every-day English language (Alcaraz-Mármol, 2015), research carried out so far has confirmed that the assumption of frequency influencing the order in which vocabulary is learnt seems to be generally valid and word frequency has so far been seen as the most effective basis for measuring vocabulary size of learners of English (Daller et al., 2007; Milton, 2009; Nation, 2001; Schmitt, 2000; 2010). As a result, vocabulary size tests are normally based on one of the available word lists, which were created based on large corpora of spoken and written texts, such as the British National Corpus (Leech, Rayson and Wilson, 2001) or the Corpus of Contemporary American English (Davies, 2010). Receptive vocabulary tests often try to estimate the total receptive vocabulary size of learners by including samples (e.g. ten words) from each 1,000 frequency level and based on the percentage of words known in that sample, extrapolating to the learners' total vocabulary size. Controlled productive tests are usually based on a similar principle and free productive vocabulary knowledge can be assessed based on the number of infrequent words (i.e. usually words beyond the 1,000 or 2,000 most commonly used words in English) that the learners use in their speech or writing (Laufer and Nation, 1999; Nation, 2001). The Vocabulary Size Test (Nation and
Beglar, 2007) used in the current study as well as some of the measures of free productive vocabulary size (namely the lexical sophistication measures) used in this study are based on the British National Corpus (BNC) and the word frequency lists created from it by Paul Nation.

\subsection{Previous studies}

Previous studies focusing on the relationship between receptive and productive vocabulary knowledge of EFL learners mostly looked at the difference between their receptive and controlled productive vocabulary size. Fan (2000), Laufer (1998), Laufer and Paribakht (1998), Tschirner (2004) and Waring (1997a; 1998) measured receptive vocabulary size using the Vocabulary Levels Test (Nation, 2001), which is based on matching words with their meanings ( 3 words, 6 meanings), and controlled productive vocabulary size using the productive version of the same test (Laufer and Nation, 1999), which is essentially a cloze test giving the initial letters of the missing words. These studies have largely concluded that the learners' receptive vocabulary is generally larger than their controlled productive vocabulary and that receptive knowledge generally precedes productive knowledge because producing a word appears to be more difficult than comprehending it (Waring, 1997a), and learners generally need to have a lot of knowledge about a word in order to be able to use it productively (Fan, 2000). There, however, does not seem to be any consistent ratio between words known receptively and words known productively and the relationship between the two kinds of vocabulary knowledge appears to be rather complicated (Fan, 2000; Laufer and Paribakht, 1998). In general, more frequent words are more likely to be known receptively as well as productively, while less frequent words known by learners receptively are not known or used productively so often (Laufer and Paribakht, 1998; Waring, 1997a). Webb (2008) questioned the choice of tests used by Fan (2000), Laufer (1998), Laufer and Paribakht (1998) and Waring (1997a) and used translation from and to L2 to test 
receptive and controlled productive vocabulary knowledge. He concluded that learners participating in his study had at least partial productive knowledge of almost all the words they knew receptively but were not able to demonstrate productive knowledge to the same degree as receptive knowledge, especially with the less-frequently used words. This generally confirms the conclusions drawn by Waring (1997a) and Laufer and Paribakht (1998). Nevertheless, all these findings are connected to the relationship between receptive and controlled productive knowledge and cannot be automatically generalized to free productive vocabulary knowledge as well.

To my knowledge, only Laufer (1998) and Laufer and Paribakht (1998) include free productive vocabulary knowledge as a third aspect of vocabulary knowledge when investigating EFL learners' vocabulary size. Both of these studies examine the relationships between three types of vocabulary knowledge: receptive, controlled productive and free productive in EFL and ESL contexts. Although they use similar methodology, the results of these two studies differ significantly as far as the relationship between receptive and free productive vocabulary knowledge is concerned. While Laufer (1998) found that free productive vocabulary knowledge did not correlate with the other two types of vocabulary knowledge at all in the EFL context with Israeli learners, Laufer and Paribakht (1998) reported significant correlations between receptive and free productive as well as between controlled productive and free productive vocabulary knowledge in both EFL (Israel) and ESL (Canada) contexts. They concluded that learners with better receptive and controlled productive vocabulary knowledge also demonstrated better free productive vocabulary knowledge. There are other studies including free productive vocabulary knowledge in their design, for example Lee (2003), but they do not focus on total vocabulary size but rather on learning and using specific vocabulary items. Lee (2003) looks at the percentage of words learners are able to use in their free production after reading them in a text and the increase in the use of these words after target vocabulary instruction.

The current study was motivated by the relative lack of studies addressing the relationship between receptive and free productive vocabulary knowledge of EFL learners and the inconsistencies in the findings of the two studies that do address this area (i.e. Laufer, 1998; Laufer and Paribakht, 1998). Another important reason for this study was the belief that comparing receptive and free productive vocabulary knowledge is important since the fact that learners produce certain words when they are "forced to" (in controlled productive tests) does not necessarily mean that they will also use these words in their free production when they have a choice, as also pointed out by Laufer (1998) and Laufer and Paribakht (1998).

\section{Method}

The design of the current study is similar to Laufer (1998) and Laufer and Paribakht (1998) in some respects but more recent tests and measures, which were not yet available at the time the two studies were conducted, are used to assess the two areas of vocabulary knowledge in focus, i.e. receptive and free productive knowledge. In addition, Laufer's (1998) and Laufer and Paribakht's (1998) definition of free productive vocabulary knowledge is broadened to include more aspects. Similarly to the two previous studies, free productive knowledge is measured based on the lexical richness of the texts written by learners. While Laufer (1998) and Laufer and Paribakht (1998) define lexical richness generally as the percentage of low-frequency words used in a text, a broader definition used by Daller et al. (2007), Milton (2009) and Read (2000) is used in the current study. The term lexical richness is used here as an umbrella term for other, more specific aspects of this construct, which include: lexical sophistication (i.e. the proportion of low-frequency words in a text, which corresponds to lexical richness in Laufer, 1998 and Laufer and Paribakht, 1998), lexical diversity (i.e. how many different words there are in a text without distinguishing between different classes of 
words or their frequency), and lexical density (i.e. the proportion of lexical words, i.e. content words, in the whole text). The current study therefore hopes to contribute to the understanding of the relationship between receptive and free productive vocabulary knowledge by looking at more aspects of free productive vocabulary knowledge than previous studies.

\subsection{Research question}

The current study attempts to answer the following research question:

RQ: What is the relationship between learners' receptive vocabulary size and lexical a) sophistication, b) diversity, and c) density in learners' free writing?

\subsection{Participants}

The participants in this study were 119 EFL learners at the very beginning of their university studies in the Czech Republic (60\% of them were men and $40 \%$ were women). The participants came from a variety of secondary schools but based on the English language part of their university entrance examination and the English language placement test that they took at the beginning of their studies, their English language ability was classified as being at B2 level or higher according to the Common European Framework of Reference for Languages (Council of Europe, n.d.). The participants were all native speakers of languages within the Slavic family of languages: Czech (70\%), Slovak (15\%) and east-Slavic languages (i.e. Russian, Ukrainian and Belorussian, 11\%,). Bilingual participants (4\%) gave Czech as one their native languages, the other one being Vietnamese, Russian and Romanian.

\subsection{Research instruments}

Nation and Beglar's (2007) Vocabulary Size Test was used to estimate total receptive vocabulary knowledge of the participants. According to Nation (2012), the test measures knowledge of the written form, the connection between the form and the meaning and to a limited extent also concept knowledge. It includes only single words (multiword units are not part of the test) and words are tested largely independently of the context. Each word is presented in a short non-defining sentence so that it is clear what part of speech it is but the sentence does not give away its meaning. Learners have to choose the correct meaning from the four options offered. Ten words are tested at each of the fourteen 1,000 frequency levels based on Nation's fourteen 1,000 word family lists created on the basis of the BNC. The score for each 1,000 level is multiplied by 100 and the sum of these scores is used to get an estimate of each learner's receptive vocabulary size. The 14,000 version was used in this study rather than the newer 20,000 version since this version had already been validated using the Rasch model by Beglar (2010) at the time the current study was undertaken (unlike the 20,000 version).

To measure the free productive vocabulary size, learners were asked to write a short story based on pictures. Providing the participants with pictures to base their story on should make it possible for them to focus their attention primarily on the language aspects of their writing rather than on trying to come up with interesting content (Weigle, 2002). The picture story provided a clear and unifying plot for all test takers to follow, which made comparing individual stories easier, and at the same time gave the writers certain freedom as to the language they wanted to use to write the story. The learners could thus write at their individual level, using either simpler or more complex language. The story chosen for this study was one of Plauen's (1996) Father and Son stories called Erfolglose Anbiederung or "Unsuccessful Ingratiation" (translation adopted from Treffers-Daller, 2013 , p. 84 , who used the same story to elicit oral narratives, see Appendix A).

\subsection{Procedure and data analysis}

Learners completed both tasks, i.e. the Vocabulary Size Test and writing the short story during their normal class using pen and paper. The Vocabulary Size Test was then scored and the results were entered into a computer. The short stories were transcribed and lexical richness was assessed using the following software: MS 
Excel, Gramulator (available on McCarthy's webpage), Coh-Metrix (available on a dedicated webpage), VocabProfiler (available on Cobb's webpage), P-Lex (available on Meara's webpage) and SketchEngine (available at ske.fi.muni.cz), all of which (except Sketch Engine) are freely available online for use or download. Table 1 provides an overview of the lexical diversity measures used and Table 2 gives information about the measures of lexical sophistication. Lexical density was calculated as the ratio between lexical words and all words in a text. A large number of lexical richness measures were used during this first stage of analysis, since there is no general consensus as to which of the measures performs the best, and using several of them in order to avoid bias is usually recommended (McCarthy and Jarvis, 2010).

B.

\begin{tabular}{|c|c|c|c|}
\hline $\begin{array}{l}\text { Name (as } \\
\text { used in } \\
\text { this study) }\end{array}$ & Formula & $\begin{array}{l}\text { Software } \\
\text { used for } \\
\text { calculation }\end{array}$ & Notes \\
\hline TTR & $\frac{\text { types }}{\text { tokens }}$ & MS Excel & \\
\hline Guiraud & $\frac{\text { types }}{\sqrt{\text { tokens }}}$ & MS Excel & $\begin{array}{l}\text { Mathematical transformation of } \\
\text { TTR. }\end{array}$ \\
\hline Herdan & $\frac{\log \text { types }}{\log \text { tokens }}$ & MS Excel & $\begin{array}{l}\text { Mathematical transformation of } \\
\text { TTR. }\end{array}$ \\
\hline Uber & $\frac{\log ^{2} \text { tokens }}{\log \text { tokens }-\log \text { types }}$ & MS Excel & $\begin{array}{l}\text { Mathematical transformation of } \\
\text { TTR. }\end{array}$ \\
\hline Maas & $\frac{\log \text { tokens }-\log \text { types }}{\log ^{2} \text { tokens }}$ & Gramulator & $\begin{array}{l}\text { Mathematical transformation of } \\
\text { TTR. }\end{array}$ \\
\hline $\begin{array}{l}\text { Lexical } \\
\text { variation }\end{array}$ & $\frac{\text { lexical types }}{\text { lexical tokens }}$ & Coh-Metrix & $\begin{array}{l}\text { Described as a separate measure of } \\
\text { lexical richness by Read }(2000) \text {. }\end{array}$ \\
\hline vocd-D & $\begin{array}{l}\text { calculated with the use } \\
\text { of dedicated software - } \\
\text { vocd }\end{array}$ & Coh-Metrix & $\begin{array}{l}\text { Blends curve fitting and sampling. } \\
\text { Final values tend to range between } \\
10 \text { and } 100 \text {, with higher values } \\
\text { indicating greater diversity. }\end{array}$ \\
\hline HD-D & $\begin{array}{l}\text { calculated with the use } \\
\text { of dedicated software }\end{array}$ & Gramulator & $\begin{array}{l}\text { Modelling of the hypergeometric } \\
\text { distribution function. Results tend } \\
\text { to highly correlate with vocd-D. }\end{array}$ \\
\hline MTLD & $\begin{array}{l}\text { calculated with the use } \\
\text { of dedicated software }\end{array}$ & Coh-Metrix & $\begin{array}{l}\text { Sequential analysis of a text - } \\
\text { similar principle to MSTTR. } \\
\text { Calculates the mean length of } \\
\text { sequences with TTR }=0.72 \text {. }\end{array}$ \\
\hline
\end{tabular}

Table 1: Lexical diversity measures used in this study Note: Measures selected for further analysis appear in bold.

In the next step, the number of variables was reduced using the Principle Component Analysis (PCA). This statistical method made it possible to create three artificial variables, each of which comprised a number of individual measures. Since it is recommended for the use of the PCA to include variables which have at least a moderate but not too strong relationships with each other, 
variables that did not correlate with any other variables within the same group or correlated only weakly (i.e. $r<.3$ ) and variables that correlated very strongly (i.e. $r=.9$ or higher) were excluded. The sample size was assessed based on Nunnally (1978) who recommends having ten times as many participants as variables, which means up to twelve variables in this case. The Kaiser-MeyerOlkin measure was used to verify the sampling adequacy.

Bivariate correlation analysis was then used to explore the relationship between receptive vocabulary size and the three dimensions of lexical richness: lexical sophistication, lexical diversity and lexical density. Spearman's Rs was used as the correlation coefficient since in many cases the distribution of the variables was not normal based on the Kolmogorov-Smirnov statistic. All computations for the purposes of the statistical analysis were done with the help of SPSS ver. 22. The strength of the relationships was interpreted according to De Vaus (2002) for details see Appendix B.

\begin{tabular}{|c|c|c|c|}
\hline $\begin{array}{l}\text { Name (as } \\
\text { used in this } \\
\text { study) }\end{array}$ & Formula & $\begin{array}{l}\text { Software used for } \\
\text { calculation }\end{array}$ & Notes \\
\hline $\begin{array}{l}\text { Adv Types 1K } \\
\text { Count }\end{array}$ & $\begin{array}{c}\text { number of types }> \\
1 \mathrm{~K}\end{array}$ & Lextutor (VocabProfiler) & \multirow{8}{*}{$\begin{array}{l}\text { Based on Lexical } \\
\text { Frequency Profile (Laufer } \\
\text { and Nation, 1995), using } \\
\text { BNC-20 word list. }\end{array}$} \\
\hline $\begin{array}{l}\text { Adv Types 2K } \\
\text { Count }\end{array}$ & $\begin{array}{c}\text { number of types }> \\
2 \mathrm{~K}\end{array}$ & Lextutor (VocabProfiler) & \\
\hline $\begin{array}{l}\text { Adv Types 1K } \\
\text { /All Types }\end{array}$ & $\frac{\text { types }>1 K}{\text { all types }}$ & $\begin{array}{c}\text { Lextutor (VocabProfiler) } \\
\text { and MS Excel }\end{array}$ & \\
\hline $\begin{array}{l}\text { Adv Types 2K } \\
\text { /All Types }\end{array}$ & $\frac{\text { types }>2 K}{\text { all types }}$ & $\begin{array}{c}\text { Lextutor (VocabProfiler) } \\
\text { and MS Excel }\end{array}$ & \\
\hline ATTR $1 \mathrm{~K}$ & $\frac{\text { types }>1 K}{\text { all tokens }}$ & $\begin{array}{c}\text { Lextutor (VocabProfiler) } \\
\text { and MS Excel }\end{array}$ & \\
\hline ATTR 2K & $\frac{\text { types }>2 K}{\text { all tokens }}$ & $\begin{array}{c}\text { Lextutor (VocabProfiler) } \\
\text { and MS Excel }\end{array}$ & \\
\hline $\begin{array}{l}\text { Adv Guiraud } \\
\text { IK }\end{array}$ & $\frac{\text { types }>1 \mathrm{~K}}{\sqrt{\text { all tokens }}}$ & $\begin{array}{c}\text { Lextutor (VocabProfiler) } \\
\text { and MS Excel }\end{array}$ & \\
\hline $\begin{array}{l}\text { Adv Guiraud } \\
2 \mathrm{~K}\end{array}$ & $\frac{\text { types }>2 K}{\sqrt{\text { all tokens }}}$ & $\begin{array}{l}\text { Lextutor (VocabProfiler) } \\
\text { and MS Excel }\end{array}$ & \\
\hline Lambda $(\lambda)$ & $\mathbf{P}_{\mathbf{N}}=\frac{\lambda^{\mathbf{N}} * \mathbf{e}^{-\lambda}}{\mathbf{N} !}$ & $\begin{array}{l}\text { P-Lex (downloaded } \\
\text { from lognostics.co.uk) }\end{array}$ & $\begin{array}{l}\text { BNC-20 word list was } \\
\text { used to decide whether a } \\
\text { word should be classified } \\
\text { as "easy" or "difficult" for } \\
\text { words not contained in P- } \\
\text { Lex dictionary. }\end{array}$ \\
\hline $\begin{array}{l}\text { Word_freq_ } \\
\text { Coh_94 }\end{array}$ & $\begin{array}{l}\text { Average word } \\
\text { frequency based on } \\
\text { the CELEX database }\end{array}$ & Coh-Metrix & \\
\hline $\begin{array}{l}\text { Lex Soph } \\
\text { BNC }\end{array}$ & $\sum_{\substack{\left.\mathrm{i}=1 \\
-\log \text { FreqBNC }_{\mathrm{i}}\right)}}^{\text {all types }}(10$ & $\begin{array}{l}\text { SketchEngine } \\
\text { (ske.fi.muni.cz) } \\
\text { and MS Excel }\end{array}$ & $\begin{array}{l}\text { FreqBNCi for each type } \\
\text { was reported by } \\
\text { SketchEngine. }\end{array}$ \\
\hline
\end{tabular}

Table 2: Lexical sophistication measures used in this study Note: Measures selected for further analysis appear in bold. 


\section{Results}

The PCA was conducted on the 11 selected measures of lexical richness which fulfilled the criteria described in section 2.4 (see the measures in bold font in Table 1 and Table 2, plus the measure of lexical density). An initial analysis was run to obtain eigenvalues for each factor in the data. Three factors had eigenvalues over the Kaiser's criterion of 1 . These factors in combination explained $79.514 \%$ of the total variance. In order to get a solution which would be easier to interpret, oblique rotation (Oblimin with Kaiser normalization) was conducted. There were 23 (41.0\%) non-redundant residuals with absolute values greater than 0.05 (the highest was .143) which points to a relatively good fit of the model. The analysis resulted in three correlated factors. Based on the items that clustered in the same factor, they were named "F1_Lex_sophistication",

"F2_Lex_diversity", "F3_Lex_density". The factor loadings after rotation for each variable are displayed in Table 3 . It is evident that the three areas of lexical richness, i.e. lexical sophistication, lexical diversity and lexical density, are different (but related) constructs since lexical sophistication measures such as the Lex Soph BNC, advanced types $>1 \mathrm{~K}$ and $>2 \mathrm{~K}$, Guiraud $>1 \mathrm{~K}$ and $2 \mathrm{~K}$ and $\lambda$ all have very high loadings on factor Fl ("lexical sophistication") and negligible loadings on the other two factors, while lexical diversity measures such as Uber, HD-D, MTLD and lexical variation have very high loadings on factor F2 ("lexical diversity") and negligible loadings on factors $\mathrm{F} 1$ and F3. Lexical density has very high loading on factor F3 ("lexical density") and negligible loadings on factors F1 and F2. The strength of the relationships was interpreted based on De Vaus (2002) - for details see Appendix B. (For descriptive statistics see Appendix

C.)

\begin{tabular}{|l|r|r|r|}
\hline & \multicolumn{3}{|c|}{ Component } \\
\cline { 2 - 4 } & F1_Lex_sophistication & F2_Lex_diversity & F3_Lex_density \\
\hline $\begin{array}{l}\text { Adv Types 2K Count } \\
\text { (LFP_2000) }\end{array}$ & .951 & -.034 & -.007 \\
\hline $\begin{array}{l}\text { Adv Types 1K Count } \\
\text { (LFP_1000) }\end{array}$ & .936 & .024 & -.071 \\
\hline Adv Guiraud 1K (AG1000) & .899 & .055 & .034 \\
\hline Adv Guiraud 2K (AG2000) & .888 & -.033 & .077 \\
\hline Lex Soph BNC & .761 & .003 & -.157 \\
\hline Lambda (PLex) & .677 & .039 & .123 \\
\hline Uber & -.007 & .937 & .132 \\
\hline Lex Variation & -.087 & .876 & -.241 \\
\hline HD-D & .105 & .865 & .079 \\
\hline MTLD & .123 & .795 & .164 \\
\hline Lex Density & -.022 & .039 & .974 \\
\hline
\end{tabular}

Table 3: The results of the Principal Component Analysis.

Note: Factor loadings over .600 appear in bold

The correlation analysis (see Table 4) shows that there is a moderately strong relationship between the receptive vocabulary size of EFL learners as assessed by the Vocabulary Size Test and lexical diversity in their written production ( $\mathrm{Rs}=.337)$. There is also a weak relationship between the receptive vocabulary size of EFL learners and lexical sophistication in their free writing $\left(\mathrm{Rs}_{\mathrm{s}}=\right.$ .190). Both of these relationships are statistically significant. No significant relationship was found between the learners' vocabulary size and lexical 
density in their writing. These results indicate that learners who know more words receptively also vary their vocabulary more when they are writing and use slightly more advanced words compared to learners with smaller receptive vocabulary sizes. Learners with larger vocabulary sizes, however, do not use more lexical words than learners with smaller vocabulary sizes.

\begin{tabular}{|l|l|r|r|r|r|}
\hline \multicolumn{2}{|l|}{} & Vocab_size_tst & $\begin{array}{c}\text { F1 Lex } \\
\text { sophistication }\end{array}$ & $\begin{array}{c}\text { F2 Lex } \\
\text { diversity }\end{array}$ & $\begin{array}{c}\text { F3 Lex } \\
\text { density }\end{array}$ \\
\hline \multirow{3}{*}{$\begin{array}{l}\text { Spearman } \\
\text { s Rho }\end{array}$} & $\begin{array}{l}\text { F1 Lex } \\
\text { sophistication }\end{array}$ & $.190^{*}$ & & & \\
\cline { 2 - 6 } & $\begin{array}{l}\text { F2 Lex } \\
\text { diversity }\end{array}$ & $.337^{* *}$ & $.366^{* *}$ & & \\
\cline { 2 - 6 } & F3 Lex density & .149 & $.186^{*}$ & $.200^{*}$ & \\
\hline
\end{tabular}

Table 4: The results of the correlation analysis.

\section{Discussion}

The results of the current study differ to a certain extent from the results of the two previous studies carried out by Laufer (1998) and Laufer and Paribakht (1998). While Laufer (1998) did not find any significant relationship between learners' receptive and free productive vocabulary knowledge (her definition of free productive knowledge corresponds to lexical sophistication in this study), the current study found a significant, albeit weak, relationship between these two areas. The relationship is, however, considerably weaker than the one found by Laufer and Paribakht (1998), where the correlation was $\mathrm{Rs}_{\mathrm{s}}=.68$ for EFL students.

The considerable differences between the three studies could be caused by a number of factors, including the sample size, native language, language proficiency of the participants and the tests used to assess the two areas of vocabulary knowledge. While 48 Hebrew high-school students with 6 to 7 years of English instruction participated in Laufer's (1998) study, Laufer and Paribakht (1998) included a total of $79 \mathrm{EFL}$ (mostly Hebrew) students. Fifty-two were high school students with similar characteristics to Laufer (1998) and 27 were university students majoring in English Language and Literature at the end of their first semester of studies. The language proficiency of these 27 students was high since they were screened by the university entrance examination and studied all subjects in English. The current study included 119 Slavic EFL students who were just starting their studies at the university. They were majoring in the fields of social, business and technical studies and none of them were English majors. It is possible that the larger sample size contributed to the significance of the findings in the current study compared to Laufer (1998). The inclusion of English majors whose English language proficiency was most likely higher than that of the participants in the current study could have caused the difference between this study and Laufer and Paribakht (1998).

The difference in the test format used to assess receptive vocabulary knowledge (Vocabulary Levels Test vs. Vocabulary Size Test) might also have contributed to the differences in the results. Additionally, while Laufer (1998) and Laufer and Paribakht (1998) analysed argumentative compositions, the current study used short stories to evaluate the participants' free productive vocabulary knowledge. The nature of the writing task might have some influence on the results since it is probable that the topic, register and style influence the choice of vocabulary to a certain extent. It is also likely that not all the low-frequency words which the 
learners knew receptively were appropriate for productive use in the current study as well as in Laufer (1998) and Laufer and Paribakht (1998). Another limitation of the current study also is that due to time constraints, information about controlled productive vocabulary knowledge of the learners was not collected. It is therefore difficult to say whether the learners would use more low-frequency words if "forced" to do so by the task.

In general, it is, however, possible to say that the current study confirms some of the conclusions made by Laufer (1998) and Laufer and Paribakht (1998). Both of these studies point out that EFL learners tend to avoid using low-frequency vocabulary in their free production even if they know the words receptively. This was generally confirmed by the current study. As the correlation between the learners' receptive vocabulary size and lexical sophistication in their free production was only very weak (even though significant), it seems that, in general, learners with larger receptive vocabulary sizes do not make much productive use of the low-frequency words they know receptively. Instead, they tend to vary more the high-frequency words. This can be seen from the differences in correlations between lexical sophistication and receptive vocabulary knowledge ( $\left.\mathrm{Rs}_{\mathrm{s}}=.190\right)$ and between lexical diversity and receptive vocabulary knowledge $\left(\mathrm{Rs}_{\mathrm{s}}=.337\right)$. This conclusion also corresponds with the results of studies looking at the difference between receptive and controlled productive vocabulary knowledge, which showed that there is a smaller gap between receptive and controlled productive vocabulary knowledge at higher frequency levels, so the majority of high frequency words known receptively are also known productively, but the gap increases with the decreasing frequency of words (Laufer, 2008; Laufer and Paribakht, 2008; Tschirner, 2004; Waring, 1998), even though Webb (2008) showed that learners were able to demonstrate at least approximate productive knowledge of the written form of most words they knew receptively in a translation test.

So why do EFL learners tend to avoid using low-frequency words in their writing? Laufer (1998) attributes this to the learners' tendency to avoid the risk of making mistakes when using infrequent words (which they might not know very well) and instead trying to make do with the high-frequency words they know well and which they might therefore consider a safe option. Laufer and Paribakht (1998) also suggest that while high-frequency words are indispensable and therefore more likely to pass from receptive to productive vocabulary knowledge, lowfrequency words are less likely to do so. They assume that this is due to the fact that learners receive less exposure to lowfrequency words and are also less likely to practise using them productively. These assumptions seem to be reasonable and there is a good chance that they could explain the avoidance of using lessfrequent words also in the current study.

As Schmitt $(2010,2014)$ points out, productive vocabulary knowledge is more advanced and difficult than receptive knowledge since to use a word well productively (even more so in free production than in controlled production), it is necessary to know a lot of information about the word and much of this information is contextual (such as collocational behaviour or register constraints). It is not clear whether there is a certain threshold, i.e. a certain minimum amount of knowledge about a word, which would be required in order for the word to pass from receptive to productive knowledge (Read, 2000). Several studies (e.g. Mondria and Wiersma, 2004; Waring, 1997b; Webb, 2009), however, concluded that the direction in which vocabulary is learned, i.e. either L2 - L1 (receptive) or L1 - L2 (productive) when learning word pairs, influences how learners are able to use the words. Receptive learning leads to larger gains in receptive knowledge, while productive learning leads to larger gains in productive knowledge. If only one method is used, then productive learning is recommended since it seems to be more effective (Webb, 2009). Webb (2005) draws attention to the fact that learners often learn vocabulary mostly receptively from reading and listening in the classroom as well as during their self-study since receptive activities seem to prevail over 
productive activities. This is generally true for the students participating in this study since they spend more time listening and reading than speaking and writing in class (partly due to relatively large class sizes which are around twenty students) and data collected for a different study show that students at that particular university generally devote more time to listening and reading than to speaking or writing also when using English outside class. This, together with the fact that teaching writing is relatively neglected in the Czech Republic (Šaffková, 2001; Chamonikolasová and Stašková, 2005), might have a negative effect on the learners' productive vocabulary knowledge in writing.

It is rather important for EFL students to develop their productive vocabulary knowledge and to use both diverse and sophisticated vocabulary (i.e. to vary the vocabulary they use and also to include low-frequency words) in their writing since this aspect of writing is assessed positively in proficiency exams such as the Cambridge English exams or the local Czech "Maturita" exam which most secondary school students take. Studies such as Daller and Phelan (2007) and Šišková (2015) showed that lexical sophistication is even more important for human raters than lexical diversity since lexical sophistication scores were found to be a good predictor of human scores for writing quality. In accordance with the comprehensible output or "pushed output" theory (Swain, 1985), it therefore seems important that teachers design activities which would require students to use the words they know receptively also productively. Although this might cause some resistance from students, triggered by anxiety and fear of making mistakes, it should be beneficial for them in the long term since pushed output has been found to facilitate learning (e.g. Basterrechea, Mayo, Leeser, 2013) or at least prevent attrition (Yamamoto, 2011). Additionally, as Hulstijn (2001) stresses, it is important to practise the words which are deemed important or useful repeatedly in order to reactivate their knowledge and facilitate automatic word access. In his view, relying on incidental receptive learning from reading or listening is not enough if words are to be used and accessed automatically. The non-existent correlation between receptive vocabulary size and lexical density in the current study is most likely due to the fact that lexical density is not influenced by receptive vocabulary knowledge but might depend on other factors, such as genre or modality.

\section{Conclusion}

The current study found that there is a significant, albeit only low to moderate, relationship between the EFL learners' receptive and free productive vocabulary knowledge. While learners who know more words (including low-frequency words) receptively tend to vary their vocabulary more in their free written production, they use only slightly more low-frequency words in their writing compared to learners with smaller receptive vocabulary sizes. This means that EFL learners tend to rely on high-frequency words in their free production rather than including lowfrequency words in their writing, even though they might know the lowfrequency words receptively. This might, however, not be a very good strategy. Making more productive use of the words they know receptively might improve the quality of the students' writing and also lead to better grades in language proficiency tests since lexical sophistication scores have been found to be a good predictor of human scores for writing quality. It is therefore essential that teachers provide situations in which students are "pushed" to use the receptively known vocabulary in their free production. This practice could encourage and accelerate the transfer of vocabulary items from receptive to productive knowledge and reduce the students' anxiety over using low-frequency words productively. 


\section{WRITING}

Write a story based on the following pictures.
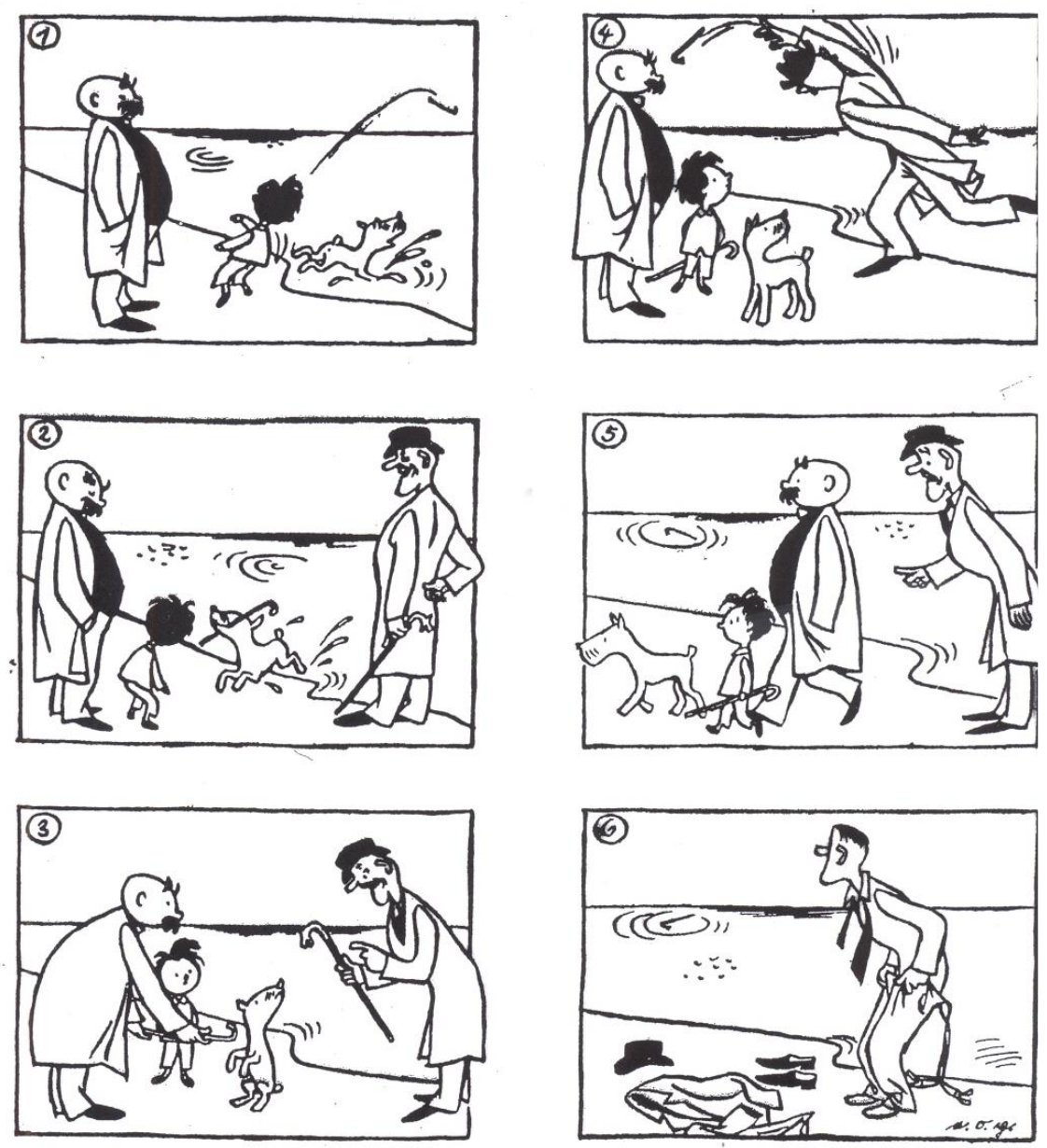

Appendix A: Prompt used to elicit stories

PLAUEN, E. O., [1952] 1996. Vater und Sohn, Band 2. Ravensburger Taschenbuch. 


\begin{tabular}{|l|l|l|}
\hline \multicolumn{1}{|c|}{ Coefficient } & \multicolumn{1}{|c|}{ Strength } & \multicolumn{1}{|c|}{ Alternate descriptors } \\
\hline 0.00 & No (linear) association & \\
\hline $0.01-0.09$ & Trivial (linear) relationship & $\begin{array}{l}\text { Very small, insubstantial, tiny, } \\
\text { practically zero }\end{array}$ \\
\hline $0.10-0.29$ & $\begin{array}{l}\text { Low to moderate (linear) relationship } \\
\text { Medium }\end{array}$ \\
\hline $0.30-0.49$ & $\begin{array}{l}\text { Substantial to very strong (linear) } \\
\text { relationship }\end{array}$ & Large, high, major \\
\hline $0.50-0.69$ & $\begin{array}{l}\text { Substantial to very strong (linear) } \\
\text { relationship }\end{array}$ & Large, high, major \\
\hline $0.70-0.89$ & Very strong (linear) relationship & Very large, very high, huge \\
\hline $0.90+$ & Near perfect & \\
\hline These interpretations apply equally to positive and negative relationships. \\
\hline
\end{tabular}

Appendix B: Interpreting strength of relationship coefficients

DE VAUS, D. A., 2002. Surveys in social research. Sydney: Allen \& Unwin. p. 259

\begin{tabular}{|l|c|r|r|r|r|r|r|}
\hline & N & Minimum & Maximum & Mean & $\begin{array}{c}\text { Std. } \\
\text { Deviation }\end{array}$ & Skewness & Kurtosis \\
\hline Vocab_size_test & 119 & 5100 & 12100 & 8364.71 & 1363.54 & .351 & .097 \\
\hline $\begin{array}{l}\text { F1 Lex } \\
\text { Sophistication }\end{array}$ & 119 & -1.7 & 3.8 & .000 & 1.0000 & .813 & 1.197 \\
\hline F2 Lex diversity & 119 & -2.4 & 2.7 & .000 & 1.0000 & .061 & -.236 \\
\hline F3 Lex density & 119 & -1.9 & 3.5 & .000 & 1.0000 & .787 & .790 \\
\hline
\end{tabular}

\section{Appendix C: Descriptive statistics}

\section{References}

ALCARAZ-MÁRMOL, G., 2015. Dispersion and frequency: Is there any difference as regards their relation to $L 2$ vocabulary gains? IJES, vol. 15, no.2, pp.1-16.

BACHMAN, L. F. and PALMER, A. S., 1996. Language testing in practice. Oxford: Oxford University Press.

BASTERRECHEA, M., MAYO, M.P.G. and LEESER, M. J., 2014. Pushed output and noticing in a dictogloss: Task implementation in the CLIL classroom. Porta Linguarum, vol. 22, pp. 7-22.

BEGLAR, D., 2010. A Rasch-based validation of the Vocabulary Size Test. Language Testing, vol.27, no.1, pp.101-118.

CHAMONIKOLASOVÁ, J. and STAŠKOVÁ, J., 2005. Some difficulties facing native speakers of Czech and Slovak in writing in English. Theory and Practice in English Studies, vol.3, pp. 5359.

COBB, T. (n.d.) VocabProfiler. [Computer software]. Retrieved October 10, 2012, from http:/ / www.lextutor.ca/vp/

COH-METRIX 3.0. (n.d.). [Computer software]. Retrieved July 2010 - August 2014, from http://tool.cohmetrix.com/

COUNCIL OF EUROPE. (n.d.). Common European framework of reference for languages: Learning, teaching, assessment. Retrieved August 10, 2010, from http://www.coe.int/t/dg4/linguistic/source/framework_en.pdf

DALLER, H., MILTON, J. and TREFFERS-DALLER J. eds., 2007. Editors' introduction. In: Modelling and assessing vocabulary knowledge. Cambridge: Cambridge University Press, pp. $1-32$. 
DALLER, H. and PHELAN D., 2007. What is in a teacher's mind? Teacher ratings of EFL essays and different aspects of lexical richness. In: H. Daller, J. Milton and J. Treffers-Daller, eds. Modelling and assessing vocabulary knowledge. Cambridge: Cambridge University Press, pp. 234-244.

DAVIES, M., 2010. The Corpus of Contemporary American English as the first reliable monitor corpus of English. Literary and Linguistic Computing, vol. 9, no.1, pp. 25-28.

DE VAUS, D. A., 2002. Surveys in social research. Sydney: Allen \& Unwin.

DUNN, L.M. and DUNN, D.M., 2007. Peabody picture vocabulary test. (4th ed.). London: Pearson Education.

FAN, M., 2000. How big is the gap and how to narrow it? An investigation into the active and passive vocabulary knowledge of L2 learners. RELC Journal, vol.31, pp.105-119.

HENRIKSEN, B., 1999. Three dimensions of vocabulary development. SSLA, vol. 21, pp. 303317.

HULSTIJN, J. H., 2001. Intentional and incidental second language vocabulary learning: A reappraisal of elaboration, rehearsal and automaticity. In: P. Robinson, ed. Cognition and second language instruction. Cambridge UK: Cambridge University Press, pp. 258-286.

LAUFER, B., 1998. The development of passive and active vocabulary in a second language: Same or different? Applied Linguistics, vol. 19, pp. 255-271.

LAUFER, B., ELDER, C., HILL, K. and CONGDON P., 2004. Size and strength: Do we need both to measure vocabulary knowledge? Language Testing, vol.21, pp. 202-226.

LAUFER, B., and GOLDSTEIN Z., 2004. Testing vocabulary knowledge: Size, strength and computer adaptiveness. Language Learning, vol.54, no.3, pp. 399-436.

LAUFER, B., and NATION, I.S.P., 1999. A vocabulary-size test of controlled productive ability. Language Testing, vol.16, no.1, pp. 33-51.

LAUFER, B. and PARIBAKHT, T., 1998. The relationship between passive and active vocabularies: Effects of language learning context. Language Learning, vol.48, pp. 365-391.

LEE, S.H., 2003. ESL learners vocabulary use in writing and the effects of explicit vocabulary instruction. System, vol.31, pp. 537-561.

LEECH, G., RAYSON, P. and WILSON A., 2001. Companion website for: Word frequencies in written and spoken English based on the British National Corpus. Retrieved August 20, 2009, from http://ucrel.lancs.ac.uk/bncfreq/.

LEWIS, M., 1993. The lexical approach: The state of ELT and the way forward. Hove, UK: Language Teaching Publications.

MCCARTHY, P., 2012. The Gramulator 6.0. [Computer software]. Retrieved August 1, 2010, from https://umdrive.memphis.edu/pmmccrth/public/software/software_index.htm

MCCARTHY, P. and JARVIS, S., 2010. MTLD, vocd-D, and HD-D: A validation study of sophisticated approaches to lexical diversity assessment. Behavior Research Methods, vol.42, no.2, pp. 381-392.

MEARA, P., 1980. Vocabulary acquisition: A neglected aspect of language learning. Language Teaching, vol.13, pp. 221-246.

MEARA, P. (n.d.). P_Lex v2.0: A program for evaluating the vocabulary used in short texts. [Computer software]. Retrieved October 16, 2011, from http://www.lognostics.co.uk/tools/index.htm

MILTON, J., 2009. Measuring second language vocabulary acquisition. Bristol: Multilingual Matters.

MONDRIA, J. and WIERSMA, B., 2004. Receptive, productive and receptive + productive L2 vocabulary learning: What difference does it make? In: P. Bogaards and B. Laufer, eds. Vocabulary in a second language: Selection, acquisition and testing. Amsterdam: Benjamins, pp. 79-100.

NATION, I.S.P., 2001. Learning vocabulary in another language. Cambridge: Cambridge University Press.

NATION, I.S.P., 2012. The Vocabulary Size Test. Unpublished. Retrieved September 10, 2012, from http://www.victoria.ac.nz/lals/about/staff/publications/paul-nation/Vocabulary-SizeTest-information-and-specifications.pdf

NATION, I.S.P. and BEGLAR, D., 2007. A vocabulary size test. The Language Teacher, vol.31, no.7, pp. 9-13.

NATION, I.S.P. and MEARA, P., 2010. Vocabulary. In: N. Schmitt, ed. An introduction to applied linguistics. London, Hodder Education, pp. 34-52. 
NUNNALLY, N.C., 1978. Psychometric theory. New York: McGraw-Hill. PLAUEN, E. O., [1952] 1996. Vater und Sohn, Band 2. Ravensburger Taschenbuch. READ, J., 2000. Assessing vocabulary. Cambridge: Cambridge University Press.

READ, J., 2007. Second language vocabulary assessment: Current practices and new directions. IJES, vol.7, no.2, pp. 105-125.

SCHMITT, N., 2000. Vocabulary in language teaching. Cambridge: Cambridge English Education.

SCHMITT, N., 2010. Researching vocabulary: $A$ vocabulary research manual. Palgrave Macmillan.

SCHMITT, N., 2014. Size and depth of vocabulary knowledge: What the research shows. Language Learning, vol.64, no.4, pp. 913-951.

SKETCH ENGINE. (n.d.). Sketch Engine [Computer software]. Retrieved April 10, 2015, from https://ske.fi.muni.cz/login/

SWAIN, M., 1985. Communicative competence: Some roles of comprehensible input and comprehensible output in its development. In: S. Gass and C. Madden, eds. Input in second I anguage acquisition. Rowley, MA: Newbury House, pp. 235-253.

ŠAFFKOVÁ, Z., 2001. The teaching of writing in the Czech Republic. In: D. Klooster, J. Steele and P. Bloem, eds. Ideas Without Boundaries: International Educational Reform through Reading, Writing and Critical Thinking. Newark, Del.: International Reading Association.

ŠIŠKOVÁ, Z., 2015. Lexical richness and textual cohesion in free written production of Slavic EFL learners. Unpublished doctoral thesis. University of Reading, UK.

TREFFERS-DALLER, J., 2011. Operationalizing and measuring language dominance. International Journal of Bilingualism, vol.15, no.2, pp. 147-163.

TREFFERS-DALLER, J., 2013. Measuring lexical diversity among L2 learners of French: An exploration of the validity of D, MTLD and HD-D as measures of language ability. In: S. Jarvis and H. Daller, eds. Vocabulary knowledge: Human ratings and automated measures.

Amsterdam: John Benjamins.

TSCHIRNER, E., 2004. Breadth of vocabulary and advanced English study: An empirical investigation. Electronic Journal of Foreign Language Teaching, vol.1, pp. 27-39.

VERMEER, A., 2001. Breadth and depth of vocabulary in relation to L1/L2 acquisition and frequency of input. Applied Psycholinguistics, vol.22, pp. 217-234.

WARING, R., 1997a. A comparison of the receptive and productive vocabulary sizes of some second language learners. Immaculata [occasional papers of Notre Dame Seishin University, Okayama], vol.1, pp. 53-68.

WARING, R., 1997b. A study of receptive and productive learning from word cards. Studies in foreign languages and literature, vol.21, pp. 94-114.

WARING, R., 1998. Receptive and productive foreign language vocabulary size II. Retrieved June, 16, 2016, from http://www.robwaring.org/papers/various/RPII.html

WEBB, S., 2005. Receptive and productive vocabulary learning: The effects of reading and writing on word knowledge. Studies in Second Language Acquisition, vol.27, no.1, pp. 3352.

WEBB, S., 2008. Receptive and productive vocabulary sizes of L2 learners. Studies in Second Language Acquisition, vol.30, pp. 79-95.

WEBB, S., 2009. The effects of receptive and productive learning of word pairs on vocabulary knowledge. RELC Journal, vol.40, no.3, pp. 360-376.

WEIGLE, S., 2002. Assessing writing. Cambridge, UK: Cambridge University Press.

YAMAMOTO, Y.M., 2011. Bridging the gap between receptive and productive vocabulary size through extensive reading. The Reading Matrix, vol.11, no.3, pp. 226-242.

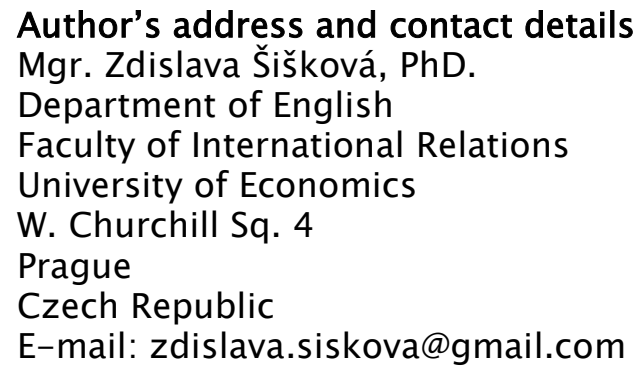

